\title{
Tool life of the edges coated with the c-BN+h-BN coatings with different structures during hard machinable steel machining
}

\author{
M. Kupczyk* and W. Misiak*
}

\begin{abstract}
In the presented paper the experimental results concerning the functional quality (durability during steel machining) of thin, superhard coatings produced on the cutting edges are described. Differences among mentioned properties of coatings mainly result from a coating structure. But the structure of coatings results from deposition parameters Superhard boron nitride coatings were deposited on insert cutting edges made of cemented carbides by the pulse-plasma method applying different values of the discharge voltage. The comparative investigations of mentioned coatings have been concerned of tool life of edges during hard machinable material machining (nitriding steel hardened in oil). In these investigations for the purpose of additional increase of coatings adhesion to substrates an interfacial layers were applied.
\end{abstract}

Keywords Wear-resistant coatings. Durability. Cutting tools.

\section{Vida, durante el mecanizado, del filo de herramientas de corte obtenidas mediante recubrimientos de $\mathrm{c}-\mathrm{BN}+\mathrm{h}-\mathrm{BN}$ con diferentes estructuras}

\begin{abstract}
Resumen En este trabajo se describen los resultados experimentales referentes a la calidad funcional (durabilidad durante el mecanizado del acero) de recubrimientos delgados, de elevada dureza del filo de corte. Las diferencias en las propiedades de los recubrimientos se deben, principalmente, a la estructura del recubrimiento. No obstante, la estructura del recubrimiento esta relacionada con los parámetros de la deposición. Recubrimientos de nitruro de boro de elevada dureza se depositaron sobre filos de corte insertados, fabricados con carburos cementados mediante el método de pulsos de plasma aplicando diferentes valores de voltaje de descarga. Las investigaciones comparativas de los mencionados recubrimientos han relacionado la vida del filo de la herramienta durante el mecanizado del material (acero nitrurado endurecido en aceite). En estas investigaciones se aplicaron capas interfaciales para aumentar la adherencia del recubrimiento.
\end{abstract}

Palabras clave Recubrimientos resistentes al desgaste. Durabilidad. Herramientas de corte.

\section{INTRODUCTION}

Increase of the resistance on an abrasion, diffusion and thermal wear of surface layer of cutting tool edges is a very important problem in metal industry. For the purpose of obtain a wear resistant surface layer of cutting tool edges heat and chemical treatment giving diffusive layers as well as coating processes of cutting tools with protective coatings joined by adhesive means are applied ${ }^{[1-8]}$. Recently, wide application because of great increase of tool life is observed for the latter of the above mentioned methods, e.g. the tool edges coated with hard films. In order to obtain such coatings, two basic techniques are used both chemical and physical vapour deposition.

For cutting edges made of cemented carbides a number of CVD and PVD methods are applied. Individual methods allow to obtain in different temperatures hard coatings with similar chemical

(*) Poznan University of Technology, Institute of Mechanical Engieering, 60-965 Poznan, Poland. 
composition but with various morphology and exploitation properties. Differences among mentioned properties of coatings mainly result from coating structure. But the structure of coatings results from deposition parameters and from individual deposition method (for example: pulse or continuous). Study carried on in laboratory and in industrial conditions for wide range of cutting tools made of cemented carbides fully proved the usefulness of the above mentioned coatings during common constructive steel machining. But investigations of these coatings, which were carried out by so called hard machinable materials machining, indicated on necessity of search for new coatings enabling to intensify machining process. Such materials should have greater resistance against abrasion and brittle cracking as well as higher hardness in high temperatures ${ }^{[1,5,7}$ and 8$]$.

In order to improve exploitation properties of cutting edges superhard coatings made of boron nitride were investigated. All coatings used in these investigations were obtained by pulse-plasma $\operatorname{method}^{[8 \text { and } 9]}$.

\section{DEPOSITION METHOD, MATERIALS AND EXPERIMENTAL PROCEDURE}

\subsection{Method of boron nitride producing}

Superhard boron nitride coatings were produced using a pulse-plasma method elaborated at department of materials science, Warsaw University of Technology ${ }^{[8 \text { and } 9]}$. In this method plasma is generated by electrical pulse discharge generating high ionized and non-isothermal plasma. The process is easy to conduct and control, a facility has a simple construction.

Pulse discharge is generated between two graphite rectangular electrodes. Pulse discharge is initialized by ignitron closing a circuit containing battery of capacitors $(200 \mu \mathrm{F})$. Ignitron is controlled by electronics board enabling adjustment of pulse discharge frequency and pulse number. Capacitor battery is supplied by DC of adjustable output up to $10 \mathrm{kV}$.

An inlet for gases is located on the level of the chamber axis in a side plate closing the chamber. Gases are supplied from a gas cylinder by pressure gauges and needle valves. Gases serve as boron carrier, which is obtained by evaporation of boroamine from a container heated through a resistance furnace. The furnace is supplied from an autotransformer. The temperature in the container is controlled by a thermocouple introduced through a teflon culvert. The working chamber is outer heated by a resistance furnace enabling a temperature in the chamber of $1,300 \mathrm{~K}$. The furnace is supplied from an autotransformer.

\subsection{Materials and experimental procedure}

For the purpose of obtain the boron nitride coatings (c-BN+h-BN) with different structures three values of discharge voltage during pulseplasma process were taken: $3 \mathrm{kV}, 4.5 \mathrm{kV}$ and $6 \mathrm{kV}$.

During durability investigations were applied a cutting insert edges made of:

- S20S (P15-P25 according to ISO) cemented carbides,

- S20S cemented carbides + boron nitride (c-BN+h-BN) coatings,

- S20S cemented carbides with interfacial layers $(\mathrm{TiC}+\mathrm{TiN})$

- S20S cemented carbides with interfacial layers $(\mathrm{TiC}+\mathrm{TiN})$ and boron nitride $(\mathrm{c}-\mathrm{BN}+\mathrm{h}-\mathrm{BN})$ coatings.

Cemented carbides insert edges were produced by Baildon, Poland

The surfaces of the cutting edges made of cemented carbides and coated with interfacial layers were prepared by the following procedures:

- degreasing in acetone with subsequent ultrasonic cleaning,

- chemical etching of cemented carbides in the $1: 1$ mixture of $20 \%$ aqueous solution of $\mathrm{KOH}$ and $20 \%$ aqueous solution of $\mathrm{K}_{3} \mathrm{Fe}(\mathrm{CN})_{6}$ or interfacial layers in $3 \mathrm{~g}$ of $\mathrm{FeCl}_{3}+10 \mathrm{ml}$ of $\mathrm{HCl}$ $+90 \mathrm{ml}$ of $\mathrm{C}_{2} \mathrm{H}_{5} \mathrm{OH}$,

- low-temperature sputtering of substrate surface,

- high-temperature sputtering of substrate surface.

In these investigations for the purpose of additional increase of durability of coated edges an interfacial layers were applied. An interfacial layers should increase the adhesion of boron nitride coatings to substrates ${ }^{[5 \text { and } 7]}$.

Interfacial layers $(\mathrm{TiC}+\mathrm{TiN})$ were deposited on cutting edges by CVD method.

In table $\mathrm{I}$ the parameters of $\mathrm{BN}$ coatings manufacturing are presented taking into account discharge voltage and surface preparation of substrates (S20S cemented carbides coated with $\mathrm{TiC}+\mathrm{TiN}$ interfacial layers). 
Table I. Selected technological parameters of boron nitride coatings manufactured by pulse-plasma method (samples with interfacial layers)

Tabla I. Parámetros seleccionados de recubrimientos de nitruro de boro fabricados mediante el método de pulsos de plasma (probetas con capas interfaciales)

\begin{tabular}{lcccc}
\hline Discharge & \multicolumn{3}{c}{ Substrate preparation } \\
\cline { 2 - 5 } voltage $U(\mathbf{k V})$ & Degreasing & Chemical etching & Low-temperature sputtering & High-temperature sputtering \\
\hline 3.0 & $\mathrm{KP1}$ & $\mathrm{KP} 2$ & $\mathrm{KP3}$ & $\mathrm{KP4}$ \\
4.5 & $\mathrm{KP5}$ & $\mathrm{KP} 6$ & $\mathrm{KP7}$ & $\mathrm{KP8}$ \\
6.0 & $\mathrm{KP9}$ & $\mathrm{KP} 10$ & $\mathrm{KP11}$ & $\mathrm{KP12}$ \\
\hline
\end{tabular}

The most important parameters of $\mathrm{BN}$ coatings formation not included in table I are: process duration $3 \mathrm{~h}$, interval between pulses: $2 \mathrm{~s}$, boroamine temperature $346 \mathrm{~K}$, sputtering duration $1 \mathrm{~h}$, gas pressure during sputtering $15 \mathrm{~Pa}$, pressure of carrying gases $100 \mathrm{~Pa}$, cooling in hydrogen.

The comparative investigations of mentioned coatings have been concerned of tool life of edges during machining of the $38 \mathrm{HMJ}$ nitriding steel hardened to 37.5 HRC.

The investigations have been also concerned evaluation of coating structure. Observations and estimation of the structure (surface morphology and fracture of coatings) of boron nitride coatings were carried out by using scanning electron microscope.

\section{RESULTS}

Wear curves for the edges coated with highmelting films during turning a $38 \mathrm{HMJ}$ nitriding steel coated with $\mathrm{BN}$ and with $(\mathrm{TiC}+\mathrm{TiN})$ interfacial layers are presented in figure 1 . On the base of the wear curves were estimated values of the tool life for coated edges with boron nitride (with interfacial layer) and comparatively for cutting edges made of S20S cemented carbides without coatings (KP01), S20S directly coated with BN coating (KPO2) and S2OS only with $\mathrm{TiC}+\mathrm{TiN}$ layer (KP03) (see Fig. 2).

In figure 3 the influence of discharge voltage values $(U=3 \mathrm{kV}, 4.5 \mathrm{kV}, 6 \mathrm{kV})$ on mean tool life of cutting edges is shown.

\section{DISCUSSION AND CONCLUSIONS}

On the base of the above results concerning edges coated with boron nitride deposited on cutting tool edges made of cemented carbides and cemented carbides coated with interfacial layers it can be stated:

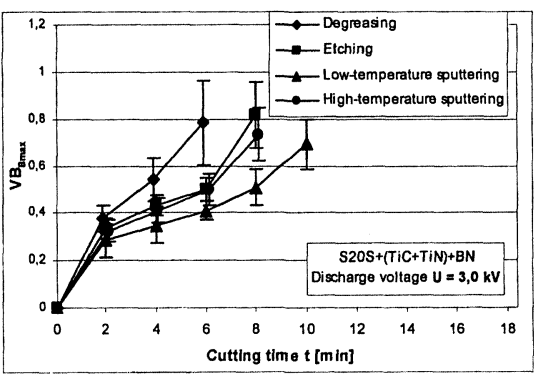

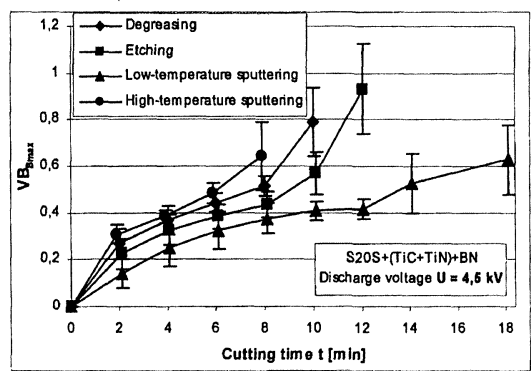

c)

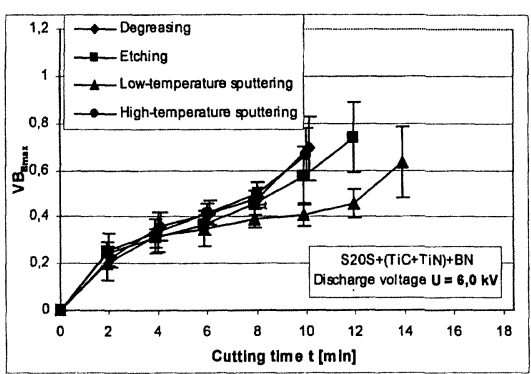

Figure 1. Graphical interpretation of wear of edges coated with c-BN+h-BN deposited on cutting edges with different surface preparation (degreasing, chemical etching, low-temperature sputtering, high-temperature sputtering), applying discharge voltage: a) $U=3 \mathrm{kV}$, b) $U=4.5 \mathrm{kV}$, c) $U=6 \mathrm{kV}$

Figura 1. Desgaste frente al tiempo de corte de herramientas con recubrimientos de $c-B N+h-B N$ depositados sobre el filo de corte con diferente preparación de superficie (desengrasado, decapado químico, baja y alta temperaturas de decapado), (a) $U=3 \mathrm{kV},(b) U=4,5 \mathrm{kV}$ y (c) $U=6 \mathrm{kV}$. 


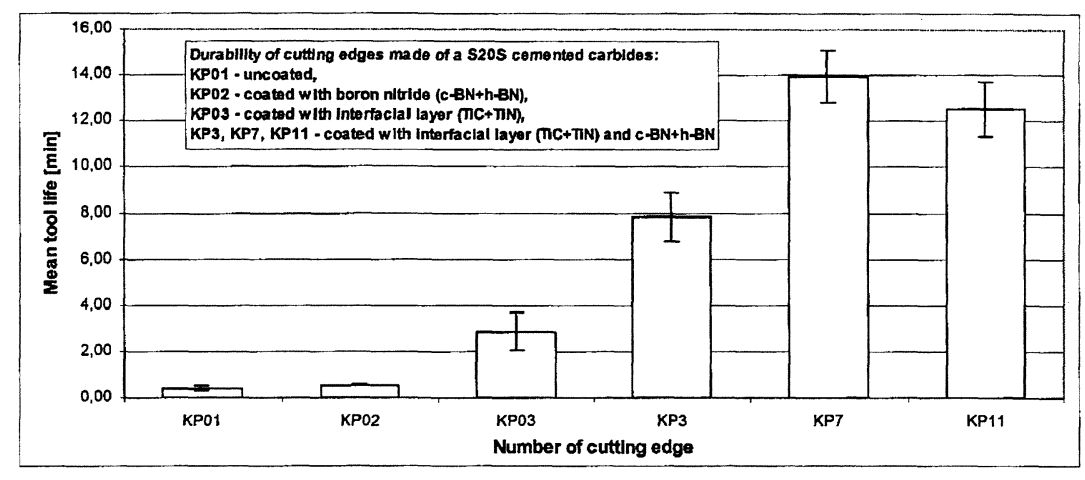

Figure 2. Mean tool life of cutting tool edges made: cemented carbides (KP-01), cemented carbides coated with boron nitride coating (KP-02), cemented carbides with TiC+TiN layer (KP-03) and cemented carbides coated with BN coating with TiC+TiN interfacial layer (KP3, KP7 and KP11).

Figura 2. Vida media de la herramienta frente al tipo de material del filo de corte: carburo cementado (KP-01), carburo cementado recubierto con nitruro de boro (KP-02), carburo cementado con capas de TiC+TiN (KP-03), y carburos cementados recubiertos con capas interfaciales de BN con Ti+TiN (KP3, KP7 y KP1 1).

a)

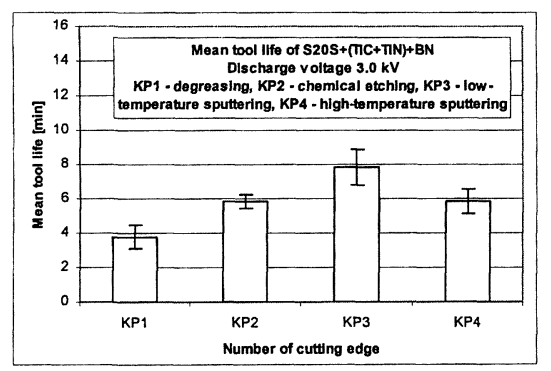

b)

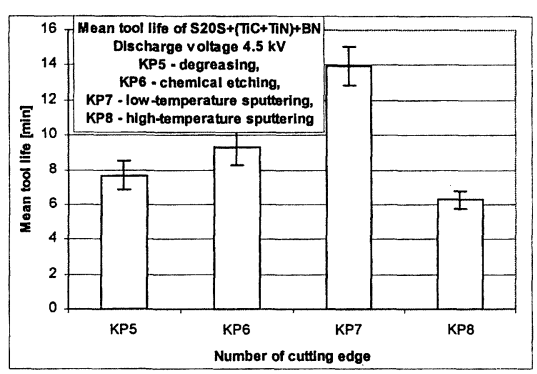

c)

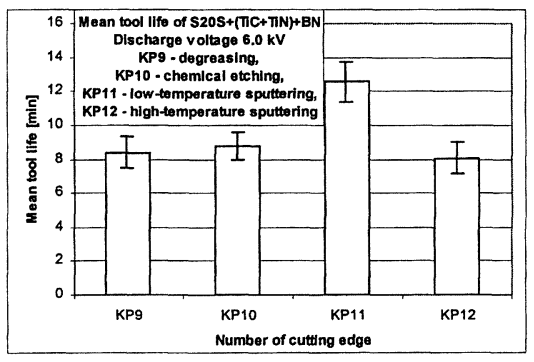

Figure 3. The influence of discharge voltage values: a) $U=3 \mathrm{kV}$, b) $U=4.5 \mathrm{kV}, \mathrm{c}) \mathrm{U}=6 \mathrm{kV}$ on mean tool life of cutting edges made of cemented carbides during turning a $38 \mathrm{HMJ}$ low alloy steel $(37.5 \mathrm{HRC})$

Figura 3. Influencia del voltaje de descarga: (a) $U=3 \mathrm{kV}$, (b) $U=4,5 \mathrm{kV}$ y (c) $U=6 \mathrm{kV}$ en la vida media del filo de herramientas de corte fabricadas con carburos cementados durante el mecanizado del 38HMJ, acero de baja aleación (37,5 HRC).

- considerable improvement of durability of edges coated with boron nitride coatings (c-BN+h-BN) obtained by the pulse-plasma method in relation to uncoated edges during turning of $38 \mathrm{HMJ}$ steel;

- the essential influence of the $\mathrm{TiC}+\mathrm{TiN}$ interfacial layers on increase of the tool life of cutting edges coated with BN coatings;

- the results of investigations are pointed at the influence of a surface preparation (degreasing, etching, low temperature sputtering, high temperature sputtering) on a tool life values;

- the investigations particularly confirmed the high tool life of $\mathrm{BN}$ coating obtained by applying low temperature sputtering of substrate surface before coating process;

- the essential influence of the discharge voltage on durability of edges coated with boron nitride and structure of coatings was observed (see Fig. 4).

\section{Acknowledgement}

Author acknowledge the financial support of the Polish State Committee for Scientific Research (KBN No. 7T08A 011 17, contract No. 962/T08/99/17) and Prof. A. Michalski for aid in manufacturing of coatings and Karol Jozwiak M.Sc. from Poznan University of Technology. 


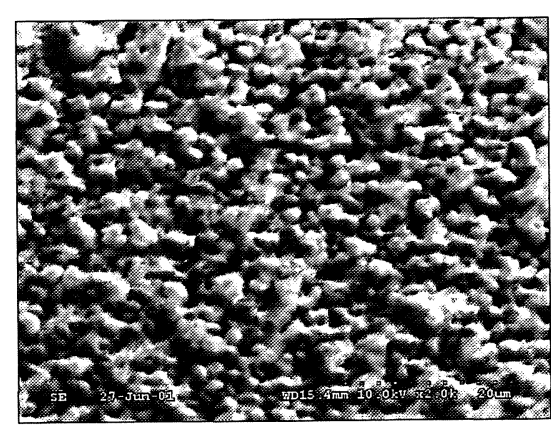

a)

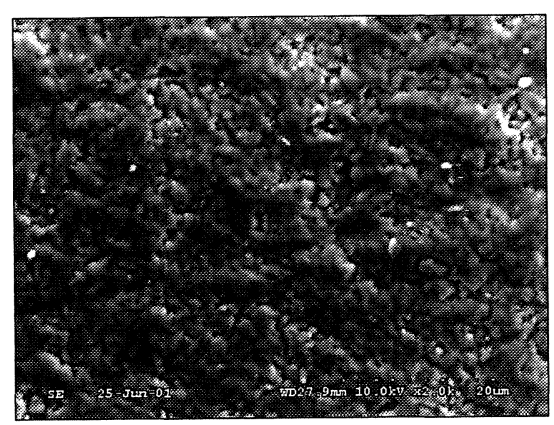

b)

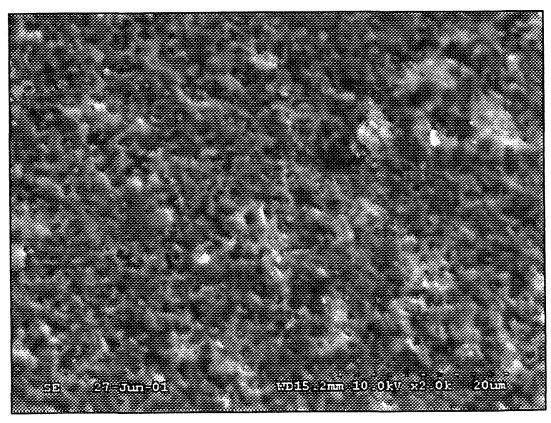

c)

Figure 4. Secondary electron images of surfaces of boron nitride coatings obtained by discharge voltages: a) $3.0 \mathrm{kV}$, b) $4.5 \mathrm{kV}$, c) $6 \mathrm{kV}$

Figura 4. Imágenes de electrones secundarios de recubrimientos de nitruro de boro obtenidos a voltajes de descarga: a) $U=3$ $k V, b) U=4,5 k V$ yc) $U=6 \mathrm{kV}$.

\section{REFERENCES}

[1] T. BURAKOWSKI, T. WIERZCHOŃ, Surface engineering of metals - principles, equipment, technologies, CRC PRESS LLC, Catalogue No. 8225, USA, 1998.

[2] W.F. Hastings, P.L.B. OXley, CIRP Annals 25 (1976) 33 38.

[3] H.E. Hinterman, Wear 100 (1984) 381-397.

[4] A. Artigas, M. Paez, Rev. Metal. Madrid 38 (2002) 339347.
[5] M. KUPCZYK, Technological and functional quality of cutting edges with wear resistant coatings, Poznan University of Technology Publishers, No 320, Poland, 1997.

[6] M. KupCzYK, Surf. Coat. Tech. 60 (1993) 446-449.

[7] W. MISIAK, Doctoral Thesis, Mechanical Engineering and Management Faculty, Poznan University of Technology, 2003.

[8] A. Michalski, S. Sobczak, M. KupczyK, Surf. Eng. 6 (2000) 349-351.

[9] M. SoKolowski, A. SoKolowska, A. Michalski, Z. Romanowski, A. RusInEk, M. WroniKowski, Thin Solid Films 30 (1981) 29-34. 